\title{
Construction of Transformational Leadership of Government Officers in Manado City
}

\author{
Micler C.S Lakat ${ }^{1} \quad$ Philotheus E A Tuerah ${ }^{2 *} \quad$ Harold Lumapou $^{3} \quad$ Jeffrey Lengkong $^{3}$ \\ 1.Doctoral Program in Education Management, Postgraduate Program 2, Manado State University, Tomohon, \\ North Sulawesi, Indonesia \\ 2.Postgraduate Program at Manado State University, Tomohon, North Sulawesi, Indonesia \\ 3.Doctoral Program in Education Management, Postgraduate Program at Manado State University, Tomohon, \\ North Sulawesi, Indonesia
}

\begin{abstract}
Research on transformational leadership has been carried out by researchers in various backgrounds and contexts, and scientific fields. Transformational leadership has implications, and an essential role in organizational performance affects employee commitment and improves work climate and varied knowledge. Research has been conducted that aims to construct the transformational leadership of government officials in the city of Manado. This research applies the case study research method. Case understanding in qualitative research can be in the form of individuals and organizations. The point in this study is the government organization of the City of Manado. Thus this research is included in the type of case study called a single case study. The research stages are observation, interview, and documentation. The research data was tested for data validity, namely, testing credibility, transferability, dependability, and confirmability. The results show that the construction of transformational leadership of government officials is multi-dimensional, namely the dimensions of work direction; communicate the vision and mission; trust in the office; develop creativity; motivate; good in the office; optimistic feelings; and instill a sense of pride.
\end{abstract}

Keywords: construction, transformational leadership, government officials, Manado

DOI: $10.7176 /$ PPAR/12-1-03

Publication date: January $31^{\text {st }} 2022$

\section{INTRODUCTION}

Efforts to realize the vision of education require efficient and effective education management. When Indonesia was in the reform era, there was a shift in the pattern of education management from centralization to decentralization. The change has caused compulsory education affairs to be no longer dominated by the central government but have been distributed to local governments. Therefore, within the framework of regional autonomy, the local government in the Regency/City is given the responsibility to manage education in accordance with the limits of authority granted by the central government.

Although local governments have been given the authority to manage education in the regions autonomously, it does not automatically run as expected. The management of education by the district/city government is not isolated, but within the framework of an open system, it constantly interacts with influencing factors, both from within (internal) and from outside (external). Internal factors can be identified from strengths and weaknesses, and external factors can be identified from opportunities and threats.

In principle, informal education as a path of environmental education is related to where educational events occur. It seems that the place where education is provided for everyone is no longer a complicated problem because apart from the dynamic changes between lifelong education and labour productivity (EvoLLLution, 2012), teaching can also be done anytime and anywhere, including in a workplace called the Dinas/Office. Agency in the autonomous district/city. Whether we realize it or not, government officials and employees are always involved in educational interactions in the workplace. In the workplace, a process of influence and influence occurs between government officials and employees and the process that happens can be referred to as the process of educational leadership in the workplace.

Previous research has shown that school managers as educational leaders play themselves as educators and company managers as entrepreneurial leaders play themselves as entrepreneurship educators (Hannon, 2018). Government officials in Manado City have pedagogical potential, and namely government officials can educate their employees because in essence employees are individuals who can be educated. Besides being pedagogical, educational interactions between government officials and employees in the workplace are also andragogy and heutagogy (Braswell, 2018). It is andragogic in that it is seen as a conceptual framework for adult education or self-directed education. Heutagogy is a framework developed as self-determined education extension of adult education. The educational interaction event in the workplace describes a situation where government officials as academic personnel can and must educate employees through a process of educational leadership in the workplace.

Research on transformational leadership has been carried out by researchers in various backgrounds and 
contexts and scientific fields. Transformational leadership has implications and an important role on organizational performance affects employee commitment, and improves the work climate and diverse knowledge (Orabi, 2016; Arif \& Akram, 2018). In quantitative research, some studies raise it as an independent variable, a dependent variable, and an intermediate or moderator variable. Likewise in qualitative research has been done by researchers. However, research on the transformational leadership construction of government officials in Manado City is still minimal and even rare in the field of educational management scientific studies that are approached from a constructivist perspective.

The constructivism perspective in this research is based on the theoretical understanding that transformational leadership is a kind of knowledge of government officials. Some of the knowledge of transformational leadership has been constructed by government officials and some have been constructed as a result of their interactions with the environment and the surrounding community. The study of government officials knowledge of transformational leadership in this context aligns with the theory of effective educational leadership that one of the dimensions is knowledge (ACECQA, 2019). That is, knowledge constructed by government officials themselves or constructed with the help of others and the socio-cultural environment contributes to the effectiveness of the transformational leadership of government officials in Manado City. Thus the analysis of the transformational leadership construction of government officials in this study is to find the dimensions of the transformational leadership construction of government officials in the process of leading employees and to find the determinants underlying the structure of transformational leadership of government officials. Research has been carried out that aims to 1). it is constructing the transformational leadership of government officials in Manado City. 2). Get the characteristics of the factors that underlie the construction of transformational leadership of government officials in the city of Manado.

\section{RESEARCH METHODS}

\section{Method}

The appropriate research method used in this research is the case study method (Gay, Mills \& Airasian, 2012; Sugiyono, 2013; Creswell, 2014). Case understanding in qualitative research can be in the form of individuals and organizations. The case in this study is the government organization of the City of Manado. Thus this research is included in the type of case study called a single case study.

A. Place and Time

The place of implementation of this research is in the city of Manado. Meanwhile, the implementation time of this research is from March to October 2021.

B. Data and Data Sources

The type of data collected and analyzed in this study is qualitative data about the construction of transformational leadership. Therefore, the primary data sources for this research are government officials. The rest is triangulated to secondary data sources, namely employees.

C. Data collection technique

Data collection techniques used are observation, interviews, and documentation studies. The researcher stops data collection activities if the data is saturated or there is no more meaningful data to collect. The three data collection techniques are described as follows.

1. Observation

This study uses a non-participant type of observation technique. This means that the researcher is not directly involved during the research and becomes a part of everyday life at the research location. Observations made by researchers are observing the state of the workplace of research subjects and attending activities related to the research data sought.

The results of the observations obtained were recorded in a field notebook. Researchers also try not to make observations that can interfere with the activities of government officials' offices. Observation activities carried out by researchers were very focused because they had prepared observation guidelines as an instrument for collecting research data. The observational data that the researcher got was immediately put into field notes, both while still at the research location and after returning from the research location.

2. Interview

This research uses an unstructured interview technique, used is an unstructured interview. The implementation of this interview used a research instrument in an interview guide. The interview guide makes it easier for researchers to record things related to research data. Sometimes the researcher conducts interviews again to ensure the clarity of the data obtained

The implementation of data collection through unstructured interviews was carried out through actions as recommended by Gay, Mills \& Airasian, 2012) below.

a. Listen more and not direct the informant.

b. Trying not to disturb government officials carrying out their duties, but mostly waiting for a response from research informants. 
c. When the informant is thinking, he will take a position of tolerance in silence, namely, the researcher will be silent by allowing the informant to feel.

d. Avoid asking the types of questions that lead or will ask questions openly.

e. Attempts to keep informants focused and ask in detail and concretely.

f. Follow up on what the informant said and ask questions if the researcher does not understand.

g. Try not to judge the views or beliefs of the informants and remain neutral to study the perspective of the informants whether the researcher agrees or not.

h. Try not to argue with the informants, especially regarding their responses, because the researcher's position is that of a recorder and not a debater.

Specifically related to interview techniques for data collection, the researcher adopted the open-ended question formulation from Lengkong (2004) (Appendix 1).

3. Documentation Study

This research also carried out document study activities that included manual and digital documents. The operational steps taken are stated as follows.

a. Develop documentation study guidelines related to the creative leadership of madrasah principals and their supporting and inhibiting factors.

b. Consult with thesis supervisors to ensure that the documentation study guidelines that the researcher has prepared are suitable for use.

d. Each time the researcher is doing a documentation study, the researcher tries first to create a good relationship to take place according to the researcher's expectations.

g. During the documentation study, although the guidelines have been prepared, in conducting the documentation study, the researcher still tries to adapt based on the essential things to be explored while reviewing the available documents.

$\mathrm{h}$. Before ending the documentation study, the researcher asks to do another documentation study if things need to be completed according to research needs.

i. After every documentation study, no more than half an hour, the researcher immediately wrote it down in the field notebooks that had been prepared.

D. Data Analysis Techniques

Analysis of research data was carried out while in the field and after returning from the field. The data analysis technique was adapted from an interactive model from Miles, Huberman \& Saldana (2014), which consisted of data reduction, data presentation, and verification/drawing conclusions.

The operational steps of data analysis carried out by researchers are as follows.

1. Data Reduction

The research data collected was very large, so the researchers carried out data reduction. To reduce data that researchers do is to summarize, select and focus on the main things, look for themes and data patterns and ignore those that are not relevant to the data needed or irrelevant to the main research problem.

2. Data Presentation

The research data that has been reduced is carried out in the form of data presentations so that they are easy to read and interpret. The way the researchers did it varied between making a brief description, made in a chart and arranging relationships between categories related to the main research problem.

3. Verification/Withdrawal of Conclusions

After being carried out interactively from data collection to data reduction than to verification/drawing of temporary conclusions and from data collection to data presentation to verification/drawing of provisional conclusions and from data reduction to data presentation and to verification/drawing of decisions to be compiled as a research report. . The researcher carried out this final conclusion drawing activity after the data was valid and did not change again or was consistent.

E. Data Validity Test

Researchers carry out testing of research data by checking or testing credibility, transferability, dependability, and confirmability (Sugiyono, 2013). Its application in this research is described as follows.

1. Credibility Test

Triangulating is the method that researchers choose to test the credibility of the data. The triangulation includes the time of research (morning, afternoon, and evening), triangulation of data collection techniques (observations, interviews, and documentation studies), and triangulation of sources (government officials, employees, and administrative staff).

2. Transferability Test

This qualitative research has transfer value if applied in other social contexts and situations. Therefore, the results of this study can be transferred if the research results are relevant to the existing social context and situation. Consequently, researchers try to make research reports by providing detailed, clear, systematic, and exceptionally reliable descriptions. 


\section{Dependability Test}

The research data obtained and compiled as a research report can be tested for data dependability. The way the researcher is trying to be open to the supervisors and other parties to audit the whole process of this research. Internal auditors carry out auditing activities, namely the promoter and co-promoter. While the actions of external auditors are the examiners.

4. Confirmability Test

The assistance of the supervisors guarantees that this research can be objective. When the researcher's confirmation test follows the correct research rules and determines the problem until the research findings are obtained, this research can be agreed upon by the dissertation supervisors and other parties. Basically, the agreement on the results of this study is a description of the existence of data confirmability testing.

\section{RESULTS AND DISCUSSION}

\section{Transformational Leadership Construction}

The concept of transformational leadership construction in this study is the transformational leadership knowledge of government officials who are applied in playing themselves as transformational leaders in the office as a workplace, how the form of expertise possessed by government officials in Manado City will depend on the data obtained by researchers.

The data on the transformational leadership construction of government officials in Manado City in this study is based on the self-perceptions of government officials and their employees. The research question posed by the researcher to the informants is how the construction of transformational leadership is? The researcher aims to analyze the structure of transformational leadership. To achieve the research objectives, the researcher collected and analyzed data.

Researcher interviews were initiated with government officials. The researchers gave the code: $\mathrm{Pj}$ with the code sequence: A, B, C, and so on and the code for the arrangement of interview activities: 1, 2, and so on. Interview results in terms of informants' answers that are not relevant to the main problem of the researcher are not included in the presentation of this data. Only six government officials in Manado City presented in this data exposure, namely officials with their respective codes $\mathrm{Pj}-\mathrm{A}, \mathrm{Pj}-\mathrm{C}$. Pj-D, Pj-F, Pj-G, and Pj-I.

The results of the researcher's interview with government officials SKPD A (W-Pj-A.1) are as follows.

Question: When you hear the question and think about the Construction of Transformational Leadership, what have you done as a government official to portray yourself as a transformational leader?

Please give the answer given according to what you know. Please write words and sentences freely according to your current situation.

(1) As long as I am entrusted as an official, I always communicate the vision and mission of the Mayor as a superior in the City Government and the vision and mission of my SKPD. I was appointed as an official because the Mayor believed in me. In that way, I also apply it so that employees trust me as their boss. That's why I always say we must trust each other every meeting at the office. The vision and mission are not only communicated to employees but also to the public or the general public because services in the office are classified as public services.

(2) During my tenure, I always motivate employees to improve performance. I try to meet the needs according to the office's ability such as regional performance allowances and work honour incentives and instil a sense of pride in the work they have achieved. Also giving directions to focus on each other's work every work apple or in a meeting at the office so that they work according to their main duties and responsibilities. I always say that I don't always motivate myself, but employees need self-motivation. That's why it is essential to motivate yourself to work, and it supports performance in the office.

\section{Informant Code: $\mathrm{Pj}-\mathrm{A}$}

Theme:

- Officials communicate the vision and mission to employees and the public/general public

- Supervisor's trust in government officials

- Trust officials to employees

- Employee trust in government officials

- Officials motivate employees

- Officials give work directions to employees

- Officials instil a sense of pride in the work achieved by employees

The results of the researcher's interview with government officials SKPD C (W-Pj-C.1) are as follows. Question: When you hear the question and think about the Construction of Transformational Leadership, what have you done as a government official to portray yourself as a transformational leader?

Please give the answer given according to what you know. Please write words and sentences freely according to your current situation. 
(1) Playing yourself as a transformative leader is indeed essential in the face of today's rapid and sometimes unpredictable changes. Facing this situation, I always encourage or motivate employees to work harder. Forms of motivation such as praise and celebrate work achievements achieved by employees. I also do essential things, such as directing employees to carry out their primary duties and responsibilities

(2) I often do something to generate a sense of optimism in employees so that they are not pressured to work and pressured by change. I also set an example or role model, such as coming to the office early and leading work apples every weekday.

(3) Facing changes in the era of the industrial revolution 4.0, I am currently trying to grow the potential for employee creativity and innovative thinking. The ways I do it, such as brainstorming in meetings, formulating work programs in the office and giving the most comprehensive opportunity to participate in the decisionmaking process.

(4) For me also should not be selfish. Employee ideas are also important. That's why I always ask for creative ideas from employees and hear many opinions from employees because I am not perfect.

Informant Code: $\mathrm{Pj}-\mathrm{C}$

Theme:

- Officials encourage or motivate

- Officials direct employees to carry out their primary duties and responsibilities

- Officials generate a sense of optimism in working for employees

- Officials set an example or role model for employees

- Officials try to grow the potential for creativity and innovative thinking of employees

- Officials ask employees for creative ideas

- Officials listen to employees' opinions a lot

The results of the researcher's interview with government officials SKPD D (W-Pj-D.1) are as follows. Question: When you hear the question and think about the Construction of Transformational Leadership, what have you done as a government official to portray yourself as a transformational leader?

Please give the answer given according to what you know. Please write words and sentences freely according to your current situation.

(1) My employees or staff are office assets with various advantages. That's why I involve them in making decisions that require creativity. That way, the original ideas and creative talents of employees can be empowered to improve office performance.

(2) I give direction to old and new employees because there are employees who need direction before carrying out work, even though the work is routinely done.

(3) There are also ways that I do, such as giving employees confidence in their work and in that way they also believe in my leadership. I think this is important because we all come from different personal backgrounds and work experiences. I can say very diverse in the office.

\section{Informant Code: $\mathrm{Pj}-\mathrm{D}$}

Theme:

- Officials involve employees in making decisions that require employee creativity

- Officials give directions to employees

- Officials trust employees $\bullet$ Officials are trusted by employees

The results of the researcher's interview with government officials SKPD F (W-Pj-F.1) are as follows.

Question: When you hear the question and think about the Construction of Transformational Leadership, what have you done as a government official to portray yourself as a transformational leader?

Please give the answer given according to what you know. Please write words and sentences freely according to your current situation.

(1) Transformational leadership is relevant to the current situation. Many things that never happened before. For example, the COVID-19 pandemic. Digital influence also needs to be anticipated. I need to instil a sense of pride in all employees with the personality of the Indonesian people. Not only pride that is selfish.

(2) Building character, building an exemplary ethical attitude and behavior for myself and my employees is necessary. That's what I do to maintain the good name of the office. Another important thing that I do and is no less important than being an example is waking up or generating a feeling of optimism at work. This is wealth in the office that needs to be strengthened so that pessimism does not exist in my office.

(3) Although what I have mentioned is important, we must not forget the mayor's vision and mission and my office's vision and mission as SKPD. These visions and missions serve as organizational guidelines. Therefore, in every meeting with employees or the community, the vision and mission is socialized through manual communication channels for Strategic Plans or digital documents via Android phones. This is important to know where the city government and SKPD organizations are going in the next 5 years.

(4) I should also mention that when compiling the Strategic Plan for SKPD, we involved internal and external 
stakeholders. Their involvement is precious because many creative ideas are contributed to preparing the SKPD's vision, mission, goals, objectives, and strategic programs.

Informant Code: $\mathrm{Pj}-\mathrm{F}$

Theme:

- Officials instil a sense of pride in the Indonesian nation's personality from employees

- Officials build exemplary officials and self-employees

- Officials evoke feelings of optimism at work

- Officials disseminate the vision and mission of the City Government and SKPD through manual and digital communication channels

- Officials develop creative ideas of stakeholders through involvement and contribution of ideas in the formulation of vision, mission, goals, targets and strategic programs.

The results of the researcher's interview with government officials SKPD G (W-Pj-G.1) are as follows. Question: When you hear the question and think about the Construction of Transformational Leadership, what have you done as a government official to portray yourself as a transformational leader?

Please give the answer given according to what you know. Please write words and sentences freely according to your current situation.

(1) I think such questions have to do with change and innovation. That's why I always motivate employees to develop creativity and innovation. Only in that way can our office exist and perform well.

(2) Another thing that I do, as the Governor said, is to set an example to act as an exemplary model for employees and the community. As a public official, you need to be exemplary. Affection and empathy are also necessary to feel valued and respected in carrying out their primary tasks.

(3) I also acknowledge the excellent work of the employee. Building a sense of optimism during the COVID-19 pandemic because employees work from home. Technological advances and their Impact on work are inevitable. Therefore, I convey the institutional and personal creative vision so that employees can also be creative both individually and in teams. That's a valuable potential in the office to deal with necessary problems with creative solutions.

Informant Code: $\mathrm{Pj}-\mathrm{G}$

Theme:

- Officials motivate employees

- Officials develop employee creativity and innovation

- Officials act as examples of self-exemplary models for employees

- Officials see the need for exemplary, compassion, and empathy

- Officials acknowledge the work of employees

- Officials build a sense of optimism during the COVID-19 pandemic

- Officials convey institutional and creative visions with the hope that employees are creative and solve problems creatively

The results of the researcher's interview with government officials SKPD G (W-Pj-G.1) are as follows.

Question: When you hear the question and think about the Construction of Transformational Leadership, what have you done as a government official to portray yourself as a transformational leader?

Please give the answer given according to what you know. Please write words and sentences freely according to your current situation.

(1) I think such questions have to do with change and innovation. That's why I always motivate employees to develop creativity and innovation. Only in that way can our office exist and perform well.

(2) Another thing that I do, as the Governor said, is to set an example to act as an exemplary model for employees and the community. As a public official, you need to be outstanding. Affection and empathy are also necessary to feel valued and respected in carrying out their main tasks.

(3) I also acknowledge the excellent work of the employee. Building a sense of optimism during the COVID-19 pandemic because employees work from home. Technological advances and their Impact on work are inevitable. Therefore, I convey the institutional and personal creative vision so that employees can also be creative both individually and in teams. That's a valuable potential in the office to deal with necessary problems with innovative solutions.

Informant Code: $\mathrm{Pj}-\mathrm{G}$
Themes:
- Officials motivate employees
- Officials develop employee creativity and innovation
- Officials act as examples of self-exemplary models for employees
- Officials see the need for exemplary, compassion, and empathy


- Officials acknowledge the work of employees

- Officials build a sense of optimism during the COVID-19 pandemic

- Officials convey institutional and creative visions with the hope that employees are creative and solve problems creatively

The researcher's interviews with government officials SKPD I (W-Pj-I.1) are as follows.

Question: When you hear the question and think about the Construction of Transformational Leadership, what have you done as a government official to portray yourself as a transformational leader?'

Please give the answer given according to what you know. Please write words and sentences freely according to your current situation.

(1) Of course, an official motivates, gives direction through coaching and sometimes through technical guidance, and changes the way employees think about office transformation when needed.

(2) I also set an example and role model for employees. For example, the work call is at 07.30 in the morning, so I try to be in the office to lead the work by that time.

Informant Code: $\mathrm{Pj}-\mathrm{I}$

Theme:

- Officials motivate employees

- Officials direct through fostering employees

- Officials direct through providing technical guidance to employees

- Officials set an example and role model for employees

After conducting interviews with government officials, the researcher turned to employees. Researchers do this to confirm the results of interviews obtained from officials. The research questions were also corrected regarding the editorial to match the interviewed informants, namely office employees in the government environment in Manado City. The employees who are determined purposively are those with work experience of more than 15 years and the rank of supervisor and group IV/a. The considerations that the researchers chose were based on the assumption that they had attended the training and education levels as candidates for officials to occupy echelon II in government in Manado City.

The employees that the researchers interviewed were 15 people from representatives of each office from government officials. However, from that number, only three employees were relevant for their answers. Applicable to what the researcher means is the employee's answer that fulfils the main research problem and the four dimensions of transformational leadership. Therefore, only the interview results of the three employees are described in the following data presentation.

The three employees referred to are codenamed: Pg-5, Pg-9, and Pg-12. The research interviews with the three employees are presented in succession as follows. The results of the researcher's interview with office employees (W-Pg-5.1) are as follows. Question: When you hear the question and think about the Construction of Transformational Leadership, what does your head office do as a government official in portraying himself as a transformational leader?

Please give the answer given according to what you know. Please write words and sentences freely according to your current situation.

(1) I'm sorry, I don't compliment my head office. The head of the office applies an effective leadership style. He is a transformational leader. The tangible evidence includes being open to convey the vision and mission of working in the office after being appointed and handing over the position, liking to hear opinions/ideas from employees, paying attention and caring for employees, and respecting the employees' human side in the office. (2) Kaban I also believe in the employees at the office, always motivates or faces challenges, also does not hesitate to ask for opinions or ideas from employees during meetings, (3) Kaban we give attention, care, and respect and interestingly instil a sense of pride with employee discipline

\author{
Informant Code: Pg-5 \\ Theme: \\ - Open officials convey the vision and mission of work \\ - Officials like to hear employees' opinions \\ - Officials pay attention, care, and respect employees \\ - Officials trust employees \\ - Officials motivate employees \\ - Officials ask for employee opinions/ideas \\ - Officials pay attention, care and respect employees \\ - Officials instil a sense of pride in employee discipline
}

The results of the researcher's interview with office employees (W-Pg-9.1) are as follows. 
Question: When you hear the question and think about the Construction of Transformational Leadership, what does your head office do as a government official in portraying himself as a transformational leader?

Please give the answer given according to what you know. Please write words and sentences freely according to your current situation.

(1) Dare I call Kaban or Badan head the style of a transformational leader. He is not afraid to take risks in making decisions. Always inspire us, employees, in a straightforward way, uphold ethics and manners and always behave ethically in leading a meeting or meeting.

(2) My Head of Agency also always communicates openly and freely with us within boundaries related to office work. Such as giving directions, directing the work, vision, mission, strategic goals and objectives of the Mayor and SKPD, and others. One more thing that we like is giving praise and the attitude of the head who always acknowledges our workability or the results of our work as employees

Informant Code: Pg-9

Theme:

- Officials are not afraid to take risks

- Officials inspire employees

- Officials uphold ethics and courtesy

- Officials are ethical in leading in the office

- Officials communicate openly with employees including the vision and mission

- Officials recognize the abilities and work results of employees

The results of the researcher's interview with office employees (W-Pg-12.1) are as follows.

Question: When you hear the question and think about the Construction of Transformational Leadership, what does your head office do as a government official in portraying himself as a transformational leader?

Informant Code: Pg-12

Theme:

- Officials develop employee creativity and innovation

- Officials provide work motivation to employees

- Officials become role models in the office

- Officials listen to employees' ideas/opinions

- Officials respect employees

- Officials celebrate outstanding employees

In addition to interviews, the researcher also conducted observations on government officials and studied documentation related to the construction of transformational leadership. The researcher observed the activities of government officials who submitted performance reports when attending coordination and evaluation meetings (rakorev) at the Mayor's Office. At the same time, the things being studied are the performance report documents of the head of SKPD (government officials).

The results of the researcher's observations include "the officials, namely the head of the Service and the Head of the Agency, submit reports on the performance achievements and constraints of the SKPD one by one in front of the Mayor and Deputy Mayor; officials use power point when presenting reports; and during submitting reports, in general, officials give confidence that they have a sense of optimism to achieve performance targets". This observational data can be interpreted as generally indicating that municipal government officials are 'optimistic'.

Meanwhile, the document that the researcher examines is the performance report document. The results of the researcher's study of the paper "generally report obstacles to implementing SKPD performance plans and efforts to overcome obstacles, which are generally overcome by fostering a sense of optimism and motivating employees" (D-Pj.A, F, G \& I-SKPD). This data is interpreted by researchers that generally City Government officials can be indicated as 'cultivating a sense of optimism and 'providing motivation'.

Based on the data exposure, the researchers obtained an overview of the themes and support for research data on the construction of transformational leadership of government officials in Manado City as shown in Appendix 2.

When analyzing the data exposure, five themes are found in the research obtained through interview data collection techniques. The five themes include taking risks in decision making, inspiring employees, respecting, celebrating employee achievements, and recognizing employees' abilities and work results. Researchers did not have them in this study because each of the five themes only came from one informant. According to the qualitative research theory, the number of data sources does not meet the primary considerations of triangulation of the number of data sources and triangulation of data collection techniques, namely interviews, observations, and documentation studies (appendix 3). 


\section{Discussion}

Research findings on the construction of transformational leadership of government officials are multidimensional. The multi-dimensional meaning in the results of this study is because there are eight dimensions of transformational leadership construction of government officials. The eight dimensions in question consist of: work direction, communicating the vision and mission, trusting in the office, developing creativity, motivating; exemplary in the office, optimistic feelings, and instil a sense of pride.

The term dimension is defined as "measurement" (Language Center, 2012; KKBI, 2021). Starting from this definition, it can be explained that the concept of dimensions in this study is a measure of the construction of transformational leadership of government officials. Then, the multi-dimensional meaning in this study refers to an understanding of more than one dimension, namely the eight dimensions of transformational leadership construction of government officials consisting of work direction; communicate the vision and mission; trust in the office; develop creativity; motivating; exemplary in the office; optimistic feelings; and instil a sense of pride.

When examining the theory of leadership in organizations that experts have developed, one of the theories of leadership that use the term dimension is Reddin, which was published in 1970 and is famous for its third or Reddin three-dimensional leadership model (Faturahman, 2019). The three dimensions referred to refer to the dimensions of leadership effectiveness: the first dimension being called less effective, the second dimension being called the primary type, and the third dimension being called more effective.

In research on transformational leadership, the term dimension is also used to describe how the leader characterizes himself as a transformational leader in the organization. There are four dimensions of transformational leadership which are abbreviated as 'four I', namely: Idealized influence (ideal influence), Inspirational motivation (inspirational motivation), Intellectual stimulation (intellectual stimulation), and Individualized consideration (individual considerations) (Ekaningsih, 2014; Jyoti \& Bhau , 2016; Sudiarta, 2018; Ogolla \& Senaji, 2018; Antonopoulou, et al., 2021). The four dimensions of transformational leadership are described as follows.

a. Ideal influence

The dimension of ideal influence is known as charisma (Sudiarta, 2018). The ideal influence dimension is shown through government officials who provide role models who behave ethically, instil a sense of pride, earn respect, and trust from employees. In the current millennial era, some employees are categorized as millennials, so the role model of government officials is fundamental to actualize. Such role modelling of government officials can inspire employees to work creatively, innovatively, and productively.

b Inspirational motivation

This dimension of inspirational motivation is shown by government officials who can articulate a creative, exciting and inspiring vision for employees in the office. Government officials can provide challenging explanation for employees with high standards, communicate optimism about future goals, and give meaning to the task at hand. Government officials who have inspirational motivation by always giving confidence and acknowledgement of employees' abilities can create intrinsic motivation for the employees themselves.

c. Intellectual stimulation

This dimension of intellectual stimulation is demonstrated by government officials who challenge assumptions, take risks, and solicit ideas from employees. Government officials who stimulate intellectually can stimulate and encourage employee creativity and innovation. Government officials must nurture and develop employees who are willing to think critically, creatively, and independently in solving work problems encountered in the office. d. Individual considerations

Government officials show this dimension of individual consideration by fulfilling the needs felt by employees. The role of government officials who act as mentors and mentors for employees is essential. Empathy, giving support, communicating openly, listening, paying attention, respecting employees, and celebrating each employee's contribution is essential for government officials in increasing the productivity of SKPD organizations.

As the researcher has previously stated, the dimensions of the transformational leadership construction of government officials found in this study have their respective indicators. These dimensions and hands can be discussed as follows. First, the extent of work direction, namely government officials giving work directions to employees to focus on their respective jobs, directing employees' work to carry out their main functions, producing through employee coaching, and directing through technical guidance to employees.

Basically, government officials' dimensions of work direction can be explained from the theory of educational management functions commonly applied by educational leaders, namely the directing leadership style. Theoretically, this leadership style is one of the leadership styles in theory called path-goal theory (Antonakis \& House (2014). According to the theory of directive leadership style, leaders or government officials provide guidance to employees as a basis for carrying out work, government officials set performance standards for employees, and government officials control the behaviour of employees if performance standards are not met. In the context of this leadership style, government officials also wisely give rewards and disciplinary 
sanctions to employees. Therefore, employees are expected to follow the rules and policies issued as code of conduct and governance in SKPD office organizations.

Second, the dimension of communicating the vision and mission, namely government officials speaking the vision and mission to employees, sharing the vision and mission to the public/general public, disseminating the vision and mission of the SKPD through manual communication channels, disseminating the vision and mission of the SKPD through digital communication channels, conveying the idea and institutional mission with the hope that employees are creative and solve problems creatively, openly share the vision and mission of work, and communicate openly with employees including the vision and mission of the SKPD.

Referring to the modern organizational structure required to have a strategic plan document, every top leader in the organization, including the top SKPD executive leadership in the government, formulates a vision and mission that is used as a guideline for implementing strategic work programs in the office. The vision and mission that have been formulated and determined need to be communicated to internal and external stakeholders of the SKPD. Thus, all budget allocations and SKPD office activities refer to the targets set in the strategic plan and at the same time, become a reference for measuring and assessing the institutional performance of SKPD.

Third, the dimension of trust in the office, namely the confidence of superiors to government officials, trust of government officials to employees, trust of employees to government officials, and giving confidence to employees.

Based on the study results by Lengkong and Rotty (2021), the theory of educational trust can be divided into interpersonal confidence and collective trust. Meanwhile, confidence in schools can be divided into teacher trust in the principal, teacher trust in teacher colleagues, confidence in students, and trust in students' parents. However, there is a difference in this study, namely the confidence of superiors in government officials.

Fourth, the dimension of developing creativity, namely government officials trying to develop the creative thinking potential of employees, asking employees for creative ideas, listening to the opinions of employees so that their creative ideas emerge, involving employees in making decisions that require employee creativity, developing stakeholder creative ideas through involvement and contribution of ideas in the formulation of vision, mission, goals, targets and strategic programs, developing employee creativity and innovation, likes to hear employee ideas/opinions, and officials ask for employee opinions/ideas.

The development of employee creativity by government officials can be explained from the theory of creative leadership. Mainemelis, Epitropaki \& Kark (2019) conceptualized three creative leadership contexts, namely: facilitating employee creativity; directing the realization of the leader's creative vision, and integrating diverse creative contributions. If it is associated with the findings in this study, then the development of creativity is relevant to innovative leaders facilitating employee creativity.

Fifth, the motivational dimension, namely government officials motivating employees to improve performance, encouraging or motivating them to work harder, and motivating employees to develop creativity and innovation.

The findings of this study are relevant to the idea of managers playing themselves as leaders. In this context, managerial leadership emerges about leaders applying the motivating function in influencing employees to achieve organizational goals. Thus it can be explained that government officials who motivate the leadership process in the office can be aligned with the use of managerial leadership in leading employees in the office.

Sixth, the dimension of exemplary in the office, namely government officials giving examples or examples to employees, building outstanding officials and self-employees, acting as examples of self-exemplary models for employees, seeing the need for exemplary, compassion, and empathy, giving examples and examples. To employees, being a role model in the office, and upholding ethics and courtesy.

Facing the challenges of the industrial revolution 4.0, which is accompanied by the digitalization movement, requires an example from leaders so that employees categorized as millennials in the office are not carried away by the flow of irresponsible and individualistic-centric values of freedom. Therefore, the leadership pattern called ing ngarso sung tulada initiated by the father of National Education Ki Handjar Dewantara, needs to be adopted and adapted in leading employees in the office. If government officials apply this leadership pattern, they must set an example or role model for employees.

Seventh, the dimension of feeling optimistic, namely government officials, generate a sense of optimism in working for employees, build a sense of optimism during the COVID-19 pandemic, and give the confidence to have a sense of optimism to achieve performance targets.

Facing the pressure of change outside the office that tends to be so fast and often unpredictable and tends to lead to a state of uncertainty in the current disruptive era, government officials need to arouse feelings of optimism in employees. This means that the strategic goals and objectives that have been set in the SKPD's strategic plan must be used as directions and guidelines to ensure that employees can be achieved. In this way, employees will feel optimistic because government officials always prevent feeling pessimistic, which can be a constraint factor. 
Eighth, the dimension of instilling a sense of pride, namely government officials instilling a sense of pride in the work achieved by employees, instilling a sense of pride in the Indonesian nation's personality from employees, and instilling a sense of satisfaction with employee discipline.

One of the characteristics of an effective leader in leading employees is to instil a sense of pride. Employees will feel the results of their work and the values of the nation's personality as a driving force in carrying out their main tasks. Naturally, everyone and including employees, need to be proud of. Therefore, it is important for government officials to always instil a sense of pride in employees for the work they have achieved and the preservation of national values in their work in the context of the Unitary State of the Republic of Indonesia (NKRI). These national values are fundamental to be strengthened by government officials to employees to avoid acts such as radicalism and not behaving Pancasilaist in the office.

This study adds constructivist theory integrated with the transformational leadership theory of government officials who portray themselves as transformational leaders. Thus, the conceptual-theoretical essence of transformational leadership construction in this study is understood based on the four-dimensional theory of effective educational leadership and one of its dimensions is knowledge because knowledge is the key to the role of educational leaders (ACECQA, 2019), including government officials who act as educational leaders.

Based on this knowledge dimension theory, government officials as educational leaders in the SKPD office work environment are recognized as transformational leaders who have knowledge of transformational leadership and are used in leading employees in the office. Knowledge of government officials about transformational leadership results from knowledge construction, either through self (personal structure) or through the assistance of other parties and socio-cultural in the SKPD office work environment as a place for adult education to take place.

Still, based on the knowledge dimension in the theory of influential educational leaders (ACECQA, 2019), the knowledge needed by government officials as educational leaders can broadly be categorized as knowledge as information, knowledge as evidence, and knowledge as understanding. The types of knowledge that are also important for the work of government officials as educational leaders are types of pedagogical expertise, theoretical knowledge, and contextual knowledge.

Pedagogical knowledge of government officials regarding the curriculum tends to be oriented towards content/content and results. Associated with the existence of government officials, the curriculum referred to refers to knowledge about transformational leadership constructed by government officials during their studies in training and the work environment in the office as a place of learning. This knowledge is the content/context used by government officials for learning to employees. Theoretical knowledge relates to applying theoretical knowledge that consciously enables government officials as education leaders to guide and cooperate with employees in developing transformational leadership learning programs for employees. While contextual knowledge requires government officials as education leaders to understand the critical nature of the context in which the SKPD is a place of work for government officials and employees.

The study of the knowledge dimension in the theory of effective educational leadership is directly related to the constructivist perspective in studying the transformational leadership of government officials. So far, researchers have tended to use behavioural theory that gave birth to a theory of leadership behavior described in various educational leadership styles. This study takes a different perspective, namely using constructivist theory as a frame of mind to describe the construction of transformational leadership of government officials. Based on such a research framework, it implies that government officials' construction of transformational leadership occurs in their interaction with their personal existence and socio-cultural environment. The structure of transformational leadership of government officials does not manifest in the dimensions that have been found but also manifests in its interaction with determinants from within (internal) and factors from outside (external) government officials. Therefore, the following section discusses the research findings on the determinants underlying the construction of transformational leadership of government officials in Manado City.

\section{CONCLUSIONS AND SUGGESTIONS \\ Conclusion}

The construction of transformational leadership of government officials is multi-dimensional, namely the dimensions of work direction; communicate the vision and mission; trust in the office; develop creativity; motivate; exemplary in the office; optimistic feelings; and instil a sense of pride.

\section{Suggestion}

Based on the study's conclusion, the researcher can put forward the following recommendations.

1. The construction of transformational leadership of government officials, which is studied from a constructivist perspective, needs to be maintained and developed continuously in the workplace.

2. The study of the psychological substance (cognitive) and the work environment (socio-cultural) needs to be considered in the professional development program of government officials because it is found in the research that these are the determining factors that underlie the construction of transformational leadership of government 
officials.

3. This research is still limited to using a qualitative approach. In the future, it is necessary to apply a quantitative approach to examine the dimensions of transformational leadership construction as a measurement instrument and to examine the correlation or influence of internal and external determinants on the transformational leadership construction of government officials.

4. The findings in this study can be transferred to other research settings and contexts that have relatively the same characteristics and are used as material for previous research for researchers interested in researching the main issues of transformational leadership construction of government officials.

\section{REFERENCES}

Antonakis, J. \& House, R. J. (2014). Instrumental leadership: Measurement and extension of transformationaltransactional leadership theory. The Leadership Quarterly. 25 (4): 746. doi:10.1016/j.leaqua. 2014.04.005

Antonopoulou, H., Halkiopoulos, C., Barlou, O. \& Beligiannis, G. N. (2021). Transformational leadership and digital skills in higher education institutes: during the COVID-19 pandemic. Emerging Science Journal, $5(1) 1-15$.

Ark, T. V. Liebtag, E. \& McClennen, N. (2020). The power of place: Authentic learning through place-based education. Alexandria, VA: ASCD.

Australian Children's Education and Care Quality Authority. (2019). The educational leader resources. Sydney: The Copyright Officer ACECQA.

Braswell, K. D. (2018). Teacher professional learning and teacher self-efficacy: A case study. Dissertasi. Pamona: Faculty of California State Polytechnic University.

Creswell, J. W. (2014). Research design: Qualitative, quantitative, and mixed methods approach. Thousand Oaks, California: Sage Publications, Inc.

de Oliveira Rodriguez, A., \& Ferreira, M.C. (2015). The Impact of transactional and transformational leadership style on organizational citizenship behaviors. Psico-USF, 20(3), 493-504. doi: 10.1590/14138271201520031.

Ekaningsih, A. S. (2014). The Effect of transformational leadership on the rmployees' performance through intervening variables of empowerment, trust, and satisfaction (A study on coal companies in East Kalimantan). European Journal of Business and Management, 6(22) 111-117.

EvoLLLution. (2012). Lifelong education and labor market needs: An examination of how ongoing learning benefits the society, the corporation and the individual. An Evolution Research Report. Halaman 1-8. www.evolllution.com/.../2012/08/evo-research-final.pdf.

Faturahman, B. M. (2019). Teori kepemimpinan situasional 3-D. Jurnal Politik dan Sosial Kemasyarakatan, 11(3) 204-217.

Faturahman, B. M. (2019). Teori Kepemimpinan Situasional 3-D. Jurnal Politik dan Sosial Kemasyarakatan, 11(3) 204-217.

Gay, L. R., Mills, G. E. \& Airasian, P. (2012). Educational research: competencies for analysis and applications. Boston: Pearson Education, Inc.

Ghasabeh, M.S., Reaiche, C., \& Soosay, C. (2015). The emerging role of transformational leadership. Journal of Developing Areas, 49(6), 459-467.

Hannon, P. D. (2018) On becoming and being an entrepreneurship educator: a personal reflection, Entrepreneurship \& Regional Development, 30:7-8, 698-721, DOI:10.1080/08985626.2018.1464259

Jyoti, J. \& Bhau, S. (2016). Transformational leadership and job performance: A study of Higher Education. Journal of Services Research, 15(2), 77-110.

Kamus Besar Bahasa Indonesia Online. (2021). Dimensi. https://www.kbbi.web.id.

Kaunang, I.R.B, Haliadi, dan Rabani, L.O. (2016). Jaringan maritim Indonesia: Sejarah toponim kota pantai di Sulawesi. Jakarta: Direktorat Sejarah, Direktorat Jenderal Kebudayaan, Kementerian Pendidikan dan Kebudayaan. hlm. 68-69. ISBN 978-602-1289-43-3.

Kim, S., \& Yoon, G. (2015). An innovation-driven culture in local government: Do senior manager's transformational leadership and the climate for creativity matter? Public Personnel Management, 44(2), 147-168. doi: 10.1177/0091026014568896

Kouzes, James. M., and Barry Z. Posner. 2017. The Leadership challenge: How to make extraordinary things happen in organizations, Hoboken: Wiley.

Kurniawan, W. Y. (2021). Implementasi teori belajar konstruktivistik Jerome Bruner dalam pembelajaran pendidikan agaman islam di SMP Negeri 9 Yogyakarta. Islamika: Jurnal Keislaman dan Ilmu Pendidikan. 3(1) 21-37.

Kurniawan, W. Y. (2021). Implementasi teori belajar konstruktivistik Jerome Bruner dalam pembelajaran pendidikan agaman islam di SMP Negeri 9 Yogyakarta. Islamika: Jurnal Keislaman dan Ilmu Pendidikan. 3(1) 21-37. 
Lengkong, J.S.J. \& Rotty, V.N.J. (2021). Kepercayaan pendidikan, kepercayaan dalam sekolah, teori, dan penelitian. Malang: Literasi Nusantara Abadi.

Lengkong, J.S.J. (2004). Perbaikan sekolah berdasarkan perspektif guru (Studi Kasus pada tiga SLTP di Kabupaten Minahasa). Malang: PPs UM Malang.

Lengkong, J.S.J. (2019). Menjadi pemimpin pendidik yang konstruktif: Sebuah ide yang waktunya telah tiba. Tomohon: MP-S3 Program Pascasarjana Unima

Mainemelis, C., Epitropaki, O. \& Kark, R. (2019). Connecting Creative Leadership's Strands of Research. Dalam Mainemelis, C., Epitropaki, O. \& Kark, R. (Eds.). Creative leadership: Contexts and prospects. New York: Routledge.

Miles, M.B., Huberman, A.M. and Saldana, J. (2014). Qualitative data analysis: A methods sourcebook. Sage, London.

Ogolla, J. \& Senaji, T.A. (2018). Transformational Leadership and Organizational Performance in Kenya. Africa International Journal of Multidisciplinary Research (AIJMR), 3 (3), 12-14.

Orabi, T. G. A. (2016). The Impact of transformational leadership style on organizational performance: Evidence from Jordan. International Journal of Human Resource Studies, 6(2), 89-102.

Pemerintah Kota Manado. (2021). Profil kota manado. Manado: Kantor Sekretaris Pemkot

Pusat Bahasa. (2012). Kamus besar bahasa Indonesia. Jakarta: Gramedia Pustaka Utama.

Razavi, S.H. \& Attarnezhad, O. (2013). Management of organizational innovation. International Journal of Business and Social Science, 4(1), 226-232.

Reeder, Lizzie A. 2014. The Impact of leadership styles on libraries, Ph.D Dissertation. United States: Capella University.

Reeder, Lizzie A. 2014. The Impact of leadership styles on libraries, Dissertation. United States: Capella University.

Scully, A. (2012). Decolonization, reinhabitation and reconciliation: Aboriginal and place-based education. Canadian Journal of Environmental Education, 17, 148-158.

Sudiarta, P. (2018). The effect pf transformation leadership, work environment and organization commitment toward job satisfaction to increase employees' performance of Warmadewa University. JAGADHITA: Jurnal Ekonomi \& Bisnis, 5(1). 8-32

Sugiyono. (2013). Metode penelitian pendidikan: Pendekatan kuantitatif, kualitatif, dan $R \&$ D. Bandung: Alfabeta.

Utama, I. L.P. (2016). Teori konstruktivisme dan teori sosiokultural: Aplikasi dalam pengajaran bahasa Inggris. Prasi: Jurnal Bahasa, Seni, dan Pengajarannya, 11(01), 4-11.

Yusuf, R.N., Musyadad, V. F., Iskandar, Y. Z. \& Widiawati, D. (2019). Implikasi asumsi konsep diri dalam pembelajaran orang dewasa. Edukatif: Jurnal Ilmu Pendidikan. 3(4) $1144-1151$.

Appendix 1. Government Official Answer Sheet Format and Employee Answer Sheet Format Government Official Answer Sheet Format

Question: When you hear the question and think about the Construction of Transformational Leadership, what have you done as a government official to portray yourself as a transformational leader?

Please answer given according to what you know. Please write words and sentences freely according to your current situation.

(1)

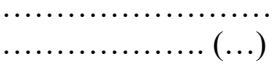

(2)

.................... (..)

(Your answer is not limited to the numbering)
Interpretation

(Don't write anything in this

space) 
Employee Answer Sheet Format

Question: When you hear the question and think about the Construction of Transformational Leadership, what has your head of office done as a government official to portray yourself as a transformational leader?

Please answer given according to what you know. Please write words and sentences freely according to your current situation.

(1)

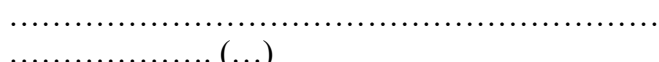

(2)

(n)

.

......................

(Your answer is not limited to the numbering)

Appendix 2. Themes and data

\begin{tabular}{|c|c|c|}
\hline No. & Theme & Interview Data \\
\hline \multirow[t]{5}{*}{1} & \multirow[t]{5}{*}{ Pengarahan kerja } & $\begin{array}{l}\text { - Pejabat memberi arahan kerja kepada pegawai agar fokus pada pekerjaan } \\
\text { masing-masing }\end{array}$ \\
\hline & & - $\quad$ Pejabat mengarahkan kerja pegawai melaksanakan tupoksi \\
\hline & & - $\quad$ Pejabat memberi pengarahan kepada pegawai \\
\hline & & - $\quad$ Pejabat mengarahkan melalui pembinaan pegawai \\
\hline & & - $\quad$ Pejabat mengarahkan melalui bimbingan teknis kepada pegawai \\
\hline \multirow[t]{7}{*}{2} & \multirow[t]{7}{*}{$\begin{array}{l}\text { Mengomunikasikan } \\
\text { visi dan misi }\end{array}$} & $\begin{array}{l}\text { - Pejabat mengomunikasikan visi dan misi kepada pegawai dan } \\
\text { publik/masyarakat umum }\end{array}$ \\
\hline & & - $\quad$ Pejabat mengomunikasikan visi dan misi kepada publik/masyarakat umum \\
\hline & & $\begin{array}{l}\text { - Pejabat sosialisasikan visi dan misi SKPD melalui saluran komunikasi } \\
\text { manual }\end{array}$ \\
\hline & & - $\quad$ Pejabat sosialisasikan visi dan misi SKPD melalui saluran komunikasi digital \\
\hline & & $\begin{array}{l}\text { - Pejabat menyampaikan visi dan misi kelembagaan dengan harapan pegawai } \\
\text { berdaya kreatif dan memecahkan masalah secara kreatif }\end{array}$ \\
\hline & & - $\quad$ Pejabat terbuka menyampaikan visi dan misi kerja \\
\hline & & - $\quad$ Pejabat berkomunikasi secara terbuka dengan pegawai termasuk visi dan misi \\
\hline \multirow[t]{6}{*}{3} & \multirow{6}{*}{$\begin{array}{l}\text { Kepercayaan dalam } \\
\text { kantor }\end{array}$} & - $\quad$ Kepercayaan atasan kepada pejabat \\
\hline & & - $\quad$ Kepercayaan pejabat kepada pegawai \\
\hline & & - $\quad$ Kepercayaan pegawai kepada pejabat pemerintah \\
\hline & & - $\quad$ Pejabat memberi kepercayaan kepada pegawai \\
\hline & & - $\quad$ Pejabat dipercayai para pegawai \\
\hline & & - $\quad$ Pejabat percaya kepada pegawai \\
\hline \multirow[t]{8}{*}{4} & \multirow{8}{*}{$\begin{array}{l}\text { Mengembangkan } \\
\text { kreativitas }\end{array}$} & - Pejabat berusaha mengembangkan potensi berpikir kreatif pegawai \\
\hline & & - $\quad$ Pejabat meminta ide kreatif kepada pegawai \\
\hline & & $\begin{array}{l}\text { Pejabat banyak mendengar pendapat para pegawai agar ide-ide kreatif } \\
\text { mereka muncul }\end{array}$ \\
\hline & & $\begin{array}{l}\text { - Pejabat libatkan pegawai dalam pembuatan keputusan yang memerlukan } \\
\text { kreativitas pegawai }\end{array}$ \\
\hline & & $\begin{array}{l}\text { - Pejabat mengembangkan ide kreatif stakeholder melalui keterlibatan dan } \\
\text { sumbangan pemikiran dalam perumusan visi, misi, tujuan, sasaran dan } \\
\text { program strategis. }\end{array}$ \\
\hline & & - $\quad$ Pejabat mengembangkan kreativitas dan inovasi pegawai \\
\hline & & - $\quad$ Pejabat suka mendengar ide/pendapat pegawai \\
\hline & & - $\quad$ Pejabat meminta pendapat/ide pegawai \\
\hline \multirow[t]{6}{*}{5} & \multirow[t]{6}{*}{ Memberi motivasi } & - $\quad$ Pejabat memberi motivasi kepada pegawai meningkatkan kinerja \\
\hline & & - $\quad$ Pejabat memberi semangat atau memberi motivasi bekerja lebih giat \\
\hline & & - $\quad$ Pejabat memotivasi pegawai mengembangan kreatitivitas dan inovasi \\
\hline & & - $\quad$ Pejabat memotivasi pegawai \\
\hline & & - $\quad$ Pejabat memberi motivasi kepada pegawai \\
\hline & & - $\quad$ Pejabat memberi motivasi kerja kepada pegawai \\
\hline
\end{tabular}

(Don't write anything in this space) 


\begin{tabular}{|c|c|c|}
\hline No. & Theme & Interview Data \\
\hline \multirow[t]{8}{*}{6} & \multirow{8}{*}{$\begin{array}{l}\text { Keteladanan dalam } \\
\text { kantor }\end{array}$} & - $\quad$ Pejabat memberi contoh atau keteladanan kepada pegawai \\
\hline & & - $\quad$ Pejabat membangun keteladanan diri pejabat dan diri pegawai \\
\hline & & - $\quad$ Pejabat membangun keteladan pegawai \\
\hline & & - $\quad$ Pejabat berperan sebagai contoh model keteladanan diri kepada pegawai \\
\hline & & - $\quad$ Pejabat memandang perlunya keteladan, rasa kasih sayang, dan rasa empati \\
\hline & & - $\quad$ Pejabat memberi contoh dan teladan kepada pegawai \\
\hline & & - $\quad$ Pejabat menjadi pola anutan di kantor \\
\hline & & - $\quad$ Pejabat menjunjung tinggi etika dan sopan santun \\
\hline \multirow[t]{4}{*}{7} & \multirow[t]{4}{*}{ Perasaan optimis } & - $\quad$ Pejabat membangkitkan rasa optimis bekerja kepada pegawai \\
\hline & & - $\quad$ Pejabat membangkitkan perasaan optimis dalam bekerja \\
\hline & & - $\quad$ Pejabat membangun rasa optimis di tengah terpaan pandemi covid-19 \\
\hline & & $\begin{array}{l}\text { - Pejabat memberi keyakinan mempunyai rasa optimis untuk mencapai target- } \\
\text { target kinerja }\end{array}$ \\
\hline \multirow[t]{3}{*}{8} & \multirow{3}{*}{$\begin{array}{l}\text { Menanamkan rasa } \\
\text { bangga }\end{array}$} & - $\quad$ Pejabat menanamkan rasa bangga dengan hasil kerja yang dicapai pegawai \\
\hline & & - $\quad$ Menanamkan rasa bangga kepribadian bangsa Indonesia dari pegawai \\
\hline & & - $\quad$ Pejabat menanamkan rasa kebanggaan dengan kedisiplinan pegawai \\
\hline No. & Tema & Data Observasi \\
\hline 1 & Perasaan optimis & $\begin{array}{l}\text { Pejabat memberi keyakinan mempunyai rasa optimis untuk mencapai target- } \\
\text { target kinerja }\end{array}$ \\
\hline No. & Tema & Data Studi Dokumentasi \\
\hline 1 & Memberi motivasi & Memberi motivasi kepada pegawai \\
\hline
\end{tabular}

Appendix 3. Analysis of Themes, Data Sources, and Data Collection Techniques

\begin{tabular}{|c|c|c|c|c|c|c|c|c|c|c|c|}
\hline \multirow[b]{2}{*}{ No. } & \multirow[b]{2}{*}{ Tema } & \multicolumn{6}{|c|}{ Pejabat Pemerintah $(\mathrm{Pj})$} & \multicolumn{3}{|c|}{ Pegawai (Pg) } & \multirow[b]{2}{*}{$\mathrm{Jlh}$} \\
\hline & & $\begin{array}{c}\mathrm{Pj}- \\
\mathrm{A}\end{array}$ & $\begin{array}{c}\mathrm{Pj}- \\
\mathrm{C}\end{array}$ & $\begin{array}{c}\mathrm{Pj}- \\
\mathrm{D}\end{array}$ & $\begin{array}{c}\mathrm{Pj}- \\
\mathrm{F}\end{array}$ & $\begin{array}{c}\mathrm{Pj}- \\
\mathrm{G}\end{array}$ & Pj-I & $\begin{array}{c}\mathrm{Pg}- \\
5 \\
\end{array}$ & $\begin{array}{c}\mathrm{Pg}- \\
6\end{array}$ & $\begin{array}{c}\mathrm{Pg}- \\
12 \\
\end{array}$ & \\
\hline \multicolumn{12}{|c|}{ WAWANCARA } \\
\hline 1 & Pengarahan kerja & $\mathrm{V}$ & $\mathrm{V}$ & $\vee$ & - & - & $\mathrm{V}$ & - & - & - & 4 \\
\hline 2 & Mengomunikasikan visi dan misi & $\mathrm{V}$ & - & - & $\mathrm{V}$ & $\mathrm{V}$ & $\mathrm{V}$ & $\mathrm{V}$ & $\mathrm{V}$ & - & 6 \\
\hline 3 & Kepercayaan dalam kantor & $\mathrm{V}$ & & $\mathrm{V}$ & - & - & - & $\mathrm{V}$ & - & - & 3 \\
\hline 4 & Mengembangkan kreativitas & - & $\mathrm{V}$ & $\mathrm{V}$ & $\mathrm{V}$ & $\mathrm{V}$ & - & $\mathrm{V}$ & - & $\mathrm{V}$ & 6 \\
\hline 5 & Memberi motivasi & $\mathrm{V}$ & $\mathrm{V}$ & - & - & $\mathrm{V}$ & $\mathrm{V}$ & $\mathrm{V}$ & - & $\mathrm{V}$ & 6 \\
\hline 6 & Keteladanan dalam kantor & - & $\mathrm{V}$ & - & $\mathrm{V}$ & $\mathrm{V}$ & $\mathrm{V}$ & $\mathrm{V}$ & - & $\mathrm{V}$ & 6 \\
\hline 7 & Perasaan optimis & - & - & - & $\mathrm{V}$ & $\mathrm{V}$ & - & - & - & - & 2 \\
\hline 8 & Menanamkan rasa bangga & $\vee$ & - & - & $\mathrm{V}$ & - & - & $\mathrm{V}$ & - & - & 3 \\
\hline \multicolumn{12}{|c|}{ OBSERVASI } \\
\hline 1 & Perasaan optimis & \multicolumn{9}{|c|}{ 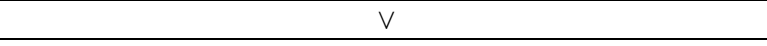 } & 1 \\
\hline \multicolumn{12}{|c|}{ STUDI DOKUMENTASI } \\
\hline 1 & Perasaan optimis & \multicolumn{9}{|c|}{$\vee$} & 1 \\
\hline 2 & Memberi motivasi & \multicolumn{9}{|c|}{$\mathrm{V}$} & 1 \\
\hline
\end{tabular}

Keterangan:

Pj: Pejabat pemeritnah dengan kode yaitu Pj-A, Pj-C. Pj-D, Pj-F, Pj-G, dan Pj-I.

Pg: Pegawai dengan kode yaitu Pg-5, Pg-9, dan Pg-12.

Jlh: Jumlah 